\title{
Surgical treatment of pressure ulcers: a two-year experience
}

\author{
Tratamento cirúrgico de úlceras por pressão: experiência de dois anos
}

Ricardo Goes Figueiras ${ }^{1}$

Study conducted in private hospitals in Manaus: Hospital Santa Júlia, Hospital UNIMED, Hospital Adventista and Hospital Nilton Lins, Manaus, AM, Brazil.

Submitted to SGP (Sistema de Gestão de Publicações/Manager Publications System) of RBCP (Revista Brasileira de Cirurgia Plástica/Brazilian Journal of Plastic Surgery).

Received: March 16, 2011 Accepted: August 9, 2011

\begin{abstract}
Background: Pressure ulcers are defined as lesions of ischemic etiology in the skin or soft tissue. These lesions are secondary to increased external pressure and usually occur over bony prominences. Classification of various stages of pressure ulcers is important for the development of therapeutic strategies. The fundamental surgical treatments are debridement and excision of underlying bursa and involved bone tissue, followed by tissue coverage. This study reports our experience in repairing pressure ulcers and analyzes patient characteristics, outcomes, and complications. Methods: A total of 33 pressure ulcers were treated in 17 patients, the most prevalent of which was sacral ulcer. The development of pressure ulcers in hospitals accounted for $82 \%$ of the cases. Treatment options included debridement, primary synthesis, random skin flaps, rhomboid skin flap, myocutaneous flaps of the gluteus maximus in V-Y, classic fasciocutaneous flaps of fascia lata, fasciocutaneous flap of fascia lata in $\mathrm{V}-\mathrm{Y}$, and posterior fasciocutaneous flaps of the thigh in V-Y. Results: Complications occurred in $39 \%$ of cases. Preoperative anemia was associated with complications. Conclusions: Pressure ulcers can be avoided in most cases, given sufficient knowledge of their pathogenesis and correct management of patients at risk. Multi-professional and family participation is essential for the treatment of patients with pressure ulcers since complications, recurrence, and the incidence of new ulcers are common. Complication risk factors such as anemia should be avoided in order to provide a better prognosis and proper closure of the ulcer.
\end{abstract}

Keywords: Pressure ulcer. Surgical flaps. Postoperative complications.

\section{RESUMO}

Introdução: Úlceras por pressão são definidas como lesões cutâneas ou de partes moles de etiologia isquêmica, secundárias ao aumento da pressão externa, predominando sobre proeminência óssea. A classificação em estágios é importante na elaboração de estratégias terapêuticas. Os princípios fundamentais no tratamento cirúrgico são: debridamento e exérese de bursa subjacente e tecido ósseo envolvido, seguida de cobertura tecidual. Este estudo teve por objetivo relatar a experiência em reparação de úlceras por pressão, analisando características dos pacientes, resultados e complicações. Método: Em 17 pacientes, foram tratadas 33 úlceras por pressão, sendo a localização sacral a mais prevalente. O desenvolvimento de úlceras por pressão no ambiente hospitalar correspondeu a $82 \%$ dos casos. As opções de tratamento foram: debridamento, síntese primária, retalhos cutâneos ao acaso, retalho cutâneo romboide, retalhos miocutâneos de glúteo máximo em V-Y, retalhos fasciocutâneos de fascia lata clássicos, retalho fasciocutâneo de fascia lata em V-Y, e retalhos fasciocutâneos posteriors da coxa em V-Y. Resultados: Complicações ocorreram em 39\% dos casos. A anemia pré-operatória foi associada a complicações. Conclusões: O conhecimento da patogênese da úlcera por pressão e o correto manejo do paciente de risco podem evitá-la na maioria dos casos. É indispensável a participação multiprofissional e dos familiares para o tratamento do paciente portador de úlcera por pressão, pois complicações, recidivas e incidência de novas úlceras são comuns. Fatores de risco para complicações, como anemia, devem ser evitados, para obtenção de melhor prognóstico e fechamento adequado da úlcera.

Descritores: Úlcera por pressão. Retalhos cirúrgicos. Complicações pós-operatórias.

1. Plastic Surgeon, full member of the Brazilian Society of Plastic Surgery, Manaus, AM, Brazil. 


\section{INTRODUCTION}

Pressure ulcers (PUs) are defined as superficial or deep lesions in the skin or soft tissue of ischemic etiology, which are secondary to increased external pressure and are usually located on a bony prominence ${ }^{1,2}$. PUs are classified in stages, which is important for the development of therapeutic strategies ${ }^{3,4}$.

PUs have etiological factors that are both intrinsic and extrinsic to the patient. Four extrinsic factors can lead to the appearance of these lesions: pressure, shear, friction, and moisture ${ }^{5}$. Pressure is considered the main causal factor and the pathological effect in the tissue can be attributed to pressure intensity, pressure duration, and tissue tolerance ${ }^{6}$. Ischemia occurs when the external pressure is greater than the pressure of tissue capillary perfusion $(32 \mathrm{mmHg})$. In the supine position, the pressure ranges from $40 \mathrm{mmHg}$ to 60 $\mathrm{mmHg}$ in the sacral, calcaneal, and occipital regions and pressure $>75 \mathrm{mmHg}$ leads to $\mathrm{PU}$ formation in the ischial region. PUs are larger over bony prominences ${ }^{7}$. A study with 649 patients and 1,604 PUs indicated that the most affected region was the ischiatic, an area of high pressure among wheelchair users. Sacral, calcaneal, and trochanteric ulcers are more common in bedridden patients ${ }^{8,9}$.

Intrinsic factors for PU include the following: age, nutritional status, tissue perfusion, the use of drugs (central nervous system depressants and hypotensive drugs), and chronic diseases (diabetes mellitus, cardiovascular diseases, stroke, etc.) $)^{6,10-13}$.

PUs may develop within 24 hours and take up to five days for manifestation. Medical professionals responsible for monitoring patients should be familiar with the major risk factors. Accordingly, prophylactic measures to eliminate continuous pressure, shear, or friction forces are essential to prevent PU formation ${ }^{14}$.

The most widely used classification is from the National Pressure Ulcer Advisory Panel, in which four progressive stages of tissue injury are described:

- stage I - intact skin, but with hyperemia that persists for more than an hour after pressure relief;

- stage II - dermis injury, with or without infection;

- stage III - subcutaneous injury and/or muscle;

- stage IV - injury to the bone and/or joint, with or without infection ${ }^{15-18}$.

The fundamentals of PU treatment have remained unchanged since 1956 when Conway \& Griffith $^{19}$ described ulcer debridement with excision of the underlying bursa and, when required, of the involved bony tissue, followed by tissue coverage $\mathrm{e}^{20,21}$.

The flap for coverage should be as large as possible and suture lines should be placed outside of the pressure area. The preparation of the flap should not violate adjacent flap areas in order to preserve future treatment options ${ }^{20}$

Various methods can be used for reconstruction including primary closure ${ }^{21}$, dermal ${ }^{22}$ or skin ${ }^{23,24}$ grafts, and fasciocutaneous $^{25-30}$, musculocutanous ${ }^{31,32}$, or muscle flaps ${ }^{33,34}$. All are effective but do not prevent recurrence ${ }^{18,35,36}$.

Ulcer recurrence or formation of new lesions often occurs after major surgical procedures, despite efforts aimed at prevention and patient education ${ }^{20}$.

The rate of recurrence after flap surgery has ranged from $3 \%$ to $82 \%$ in the last 50 years $^{37}$. Ulcer recurrence in a followup study of patients from one to 71 postoperative months (an average of nine months) was $69 \%{ }^{38}$. The complication rate is approximately $36 \% \%^{37,38}$.

Good nutritional status and appropriate management of blood glucose may improve the rate of surgical success. Serum albumin levels of $<3.2 \mathrm{ng} / \mathrm{dl}$ are associated with flap dehiscence ${ }^{37}$. Although several studies have reported that lower than normal serum protein does not necessarily result in healing deficit, surgery is often delayed until serum albumin levels are normal ${ }^{39}$.

This study reports the experience in PU repair by analyzing patient characteristics, complications, and results.

\section{METHODS}

From March 2008 to March 2010, a descriptive and longitudinal study was conducted in patients with PU admitted to private hospitals.

A protocol was prepared and assessed with the following data: gender, age, environment in which the PU developed, location, classification according to the National Pressure Ulcer Advisory Panel ${ }^{18}$, treatment, postoperative complications, success rate, and recurrence one month after surgery.

Preoperative laboratory tests such as capillary blood glucose, serum albumin, and hemoglobin were considered for possible correlation with postoperative complications $\mathrm{s}^{37,39}$.

The following aspects were considered for risk factor assessment in PU development: age, occurrence of spinal cord injury, urinary or fecal incontinence, and deficiency of albumin and hemoglobin in serum.

PU was assessed for location: sacral, ischial, trochanteric, calcaneal, occipital, and ear.

Regarding the type of treatment, only the surgical option for known techniques was described: uncoated tissue debridement, primary closure ${ }^{21}$, rhomboid skin flaps ${ }^{24}$, random flaps $^{23,24}$, myocutaneous flaps of gluteus maximus in $\mathrm{V}-\mathrm{Y}^{40-42}$, classical fasciocutaneous flaps of fascia lata ${ }^{43}$, fasciocutaneous flaps of fascia lata in V-Y, and posterior fasciocutaneous flaps of the thigh in $\mathrm{V}-\mathrm{Y}^{20,44}$.

Debridement was performed after marking the ulcer with methylene blue for complete removal of the bursa ${ }^{45}$. Suction drains were used if the surgeon found it necessary. 
The treatment was assessed through success and recurrence rates of PU. The success rate was determined by including ulcers that healed one month after surgery ${ }^{15}$. The recurrence rate was determined by including cases in which the injury reappeared more than one month after healing. The presence or absence of complications was assessed during the postoperative period and the following were described: postoperative infection at the surgical site, hematoma, wound dehiscence (smaller, length $<3 \mathrm{~cm}$; and larger, length $>3 \mathrm{~cm})$, and total $(>30 \%)$ or partial $(<30 \%)$ flap necrosis.

PU was considered chronic in cases where the onset time was longer than three months ${ }^{15}$.

The Mann-Whitney test was used for statistical analysis.

\section{RESULTS}

A total of 17 patients, 10 men and 7 women with ages ranging from 21 to 89 years (an average of 64 years), were assessed.

A total of 33 PUs were surgically treated. PUs were most prevalent in the sacral region (16 cases), followed by the trochanteric, calcaneal, ischial, occipital, and ear regions (Figure 1).

PU development in hospitals and at home accounted for $82 \%$ and $18 \%$ of the cases, respectively.

According to the classification of the National Pressure Sore Advisory Panel (1989), the prevalence of grade III and IV ulcers was $42 \%$ and the prevalence of grade II was $15 \%$. Grade III and IV ulcers were prevalent in the sacral and trochanteric regions (Figure 2).

The surgical treatment was based on the classification, the area of occurrence, the patient's general condition, and the availability of flap donor area.

All patients who underwent surgery with the use of flaps for tissue coverage also underwent debridement of

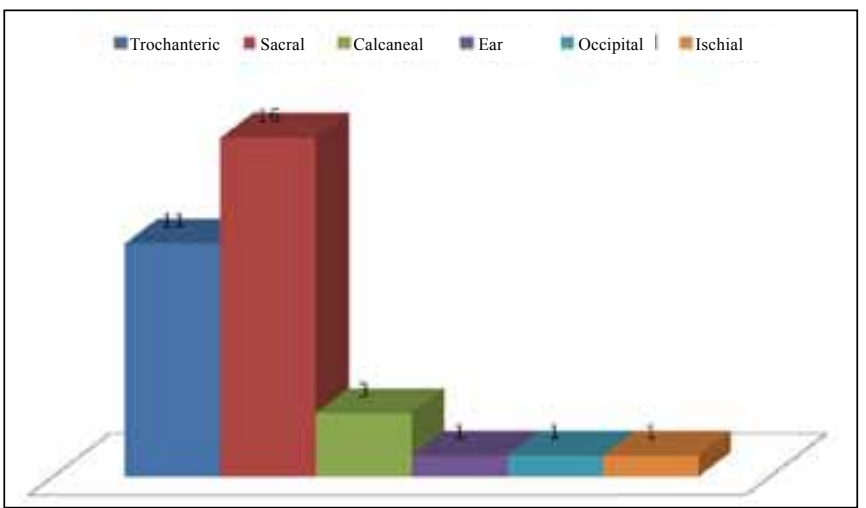

Figure 1 - Graphic representation of the regions affected by pressure ulcers. granulation tissue and bursa during the same surgical procedure. In the case of grade III and IV ulcers, patients underwent partial osteotomy for necrosis excision and/or reduction of bony prominences (Figure 3 ).

Coverage of sacral and trochanteric ulcers with a posterior fasciocutaneous flap in $\mathrm{V}-\mathrm{Y}$ of the thigh was performed in one patient. The treatment distribution for each region affected by PU is shown in Figure 4.

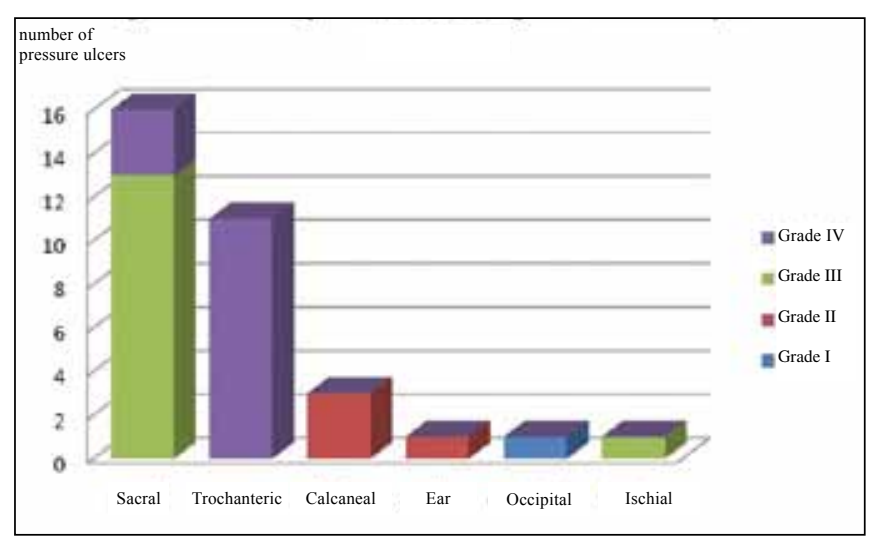

Figure 2-Distribution of ulcers according to classification and location.

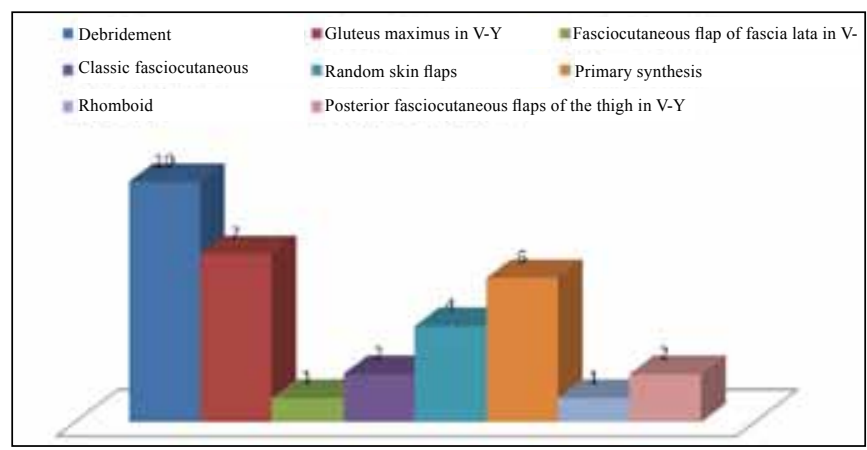

Figure 3 - Distribution of treatment.

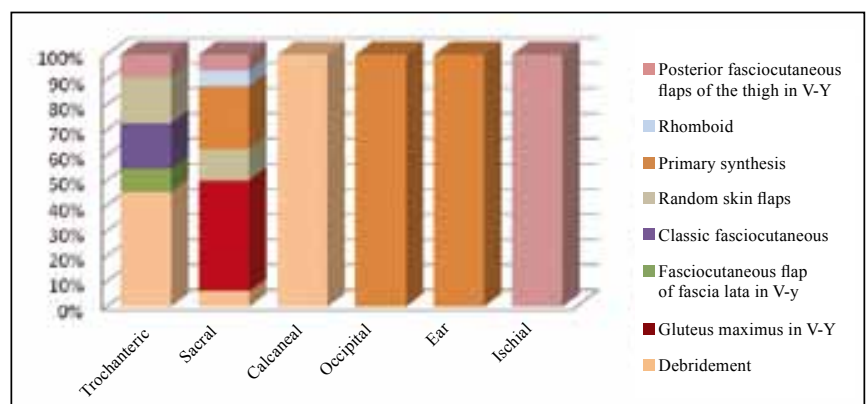

Figure 4 - Distribution by regions affected by pressure ulcers and types of treatment. 
Regarding risk factors, 15 patients were bedridden without spinal cord injury and 2 had spinal cord injuries. The spinal cord injury cases included one case of paraplegia and one of hemiplegia, both of which resulted from traumatic injury from a firearm bullet. The patient with hemiplegia had an ischial ulcer.

Only one patient was not incontinent whereas 10 patients had fecal and urinary incontinence and 6 had only urinary incontinence.

Complications did not occur in 20 out of $33(61 \%)$ treated PUs. Complications related to 13 (39\%) ulcers are shown in Figure $5 ; 18 \%$ of these complications corresponded to sacral ulcers with V-Y flaps of the gluteus maximus.

Laboratory tests indicated that blood glucose was maintained within the normal level during the preoperative and postoperative periods. Only one patient had serum albumin and hemoglobin within the normal range. The average serum albumin level was $2.7 \mathrm{ng} / \mathrm{dl}$, with equal distribution between complicated and uncomplicated cases. No relationship between below normal serum protein concentration levels and postoperative complications was found. One patient had a preoperative hemoglobin level $<10 \mathrm{ng} / \mathrm{dl}$.

The Mann-Whitney test was applied to the variables and showed that hemoglobin levels between $10 \mathrm{ng} / \mathrm{dl}$ and $11 \mathrm{ng} /$ dl were significantly associated with patient complications $(\mathrm{P}<0.05)$.

The success rate assessed per patient after one month of surgery was $53 \%$ (9 patients). PU recurrence occurred in $3(18 \%)$ patients after an average of six months of followup, 2 patients could not be assessed after one month of surgery because of death from other causes, and 2 patients had chronic ulcers, one with sacral ulcer and another with ischial ulcer (Figures 6 to 29).

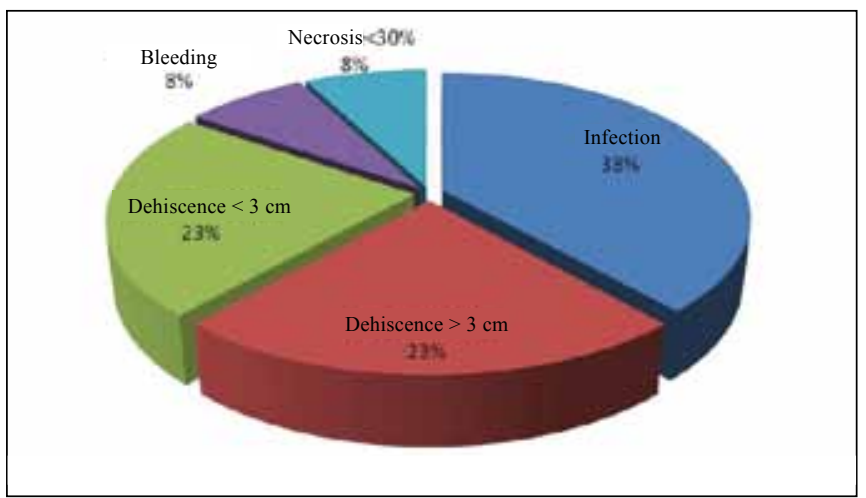

Figure 5 - Distribution of immediate ulcer complications after treatment.

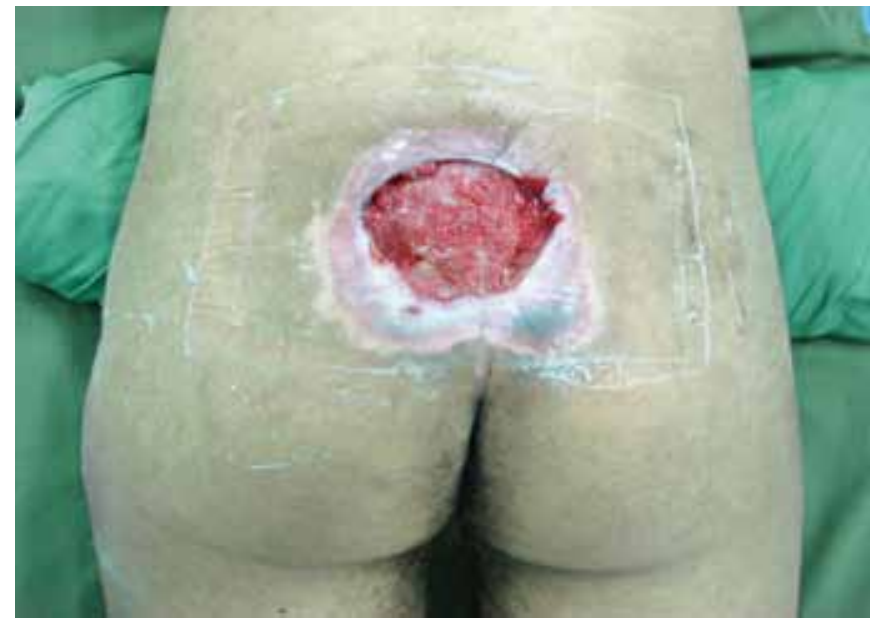

Figure 6 - Sacral ulcer in a 21-year-old patient with spinal cord injury from a firearm bullet.

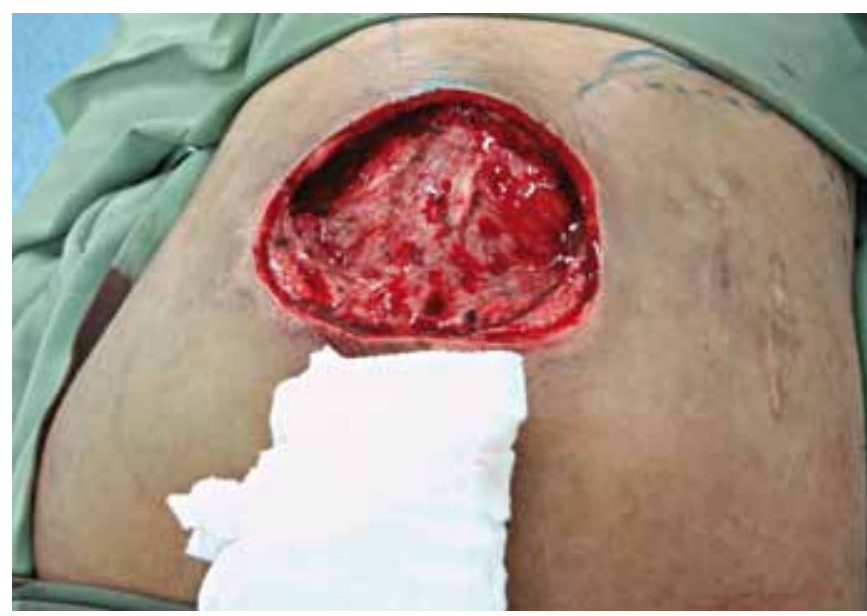

Figure 7 - Intraoperative sacral ulcer after debridement.

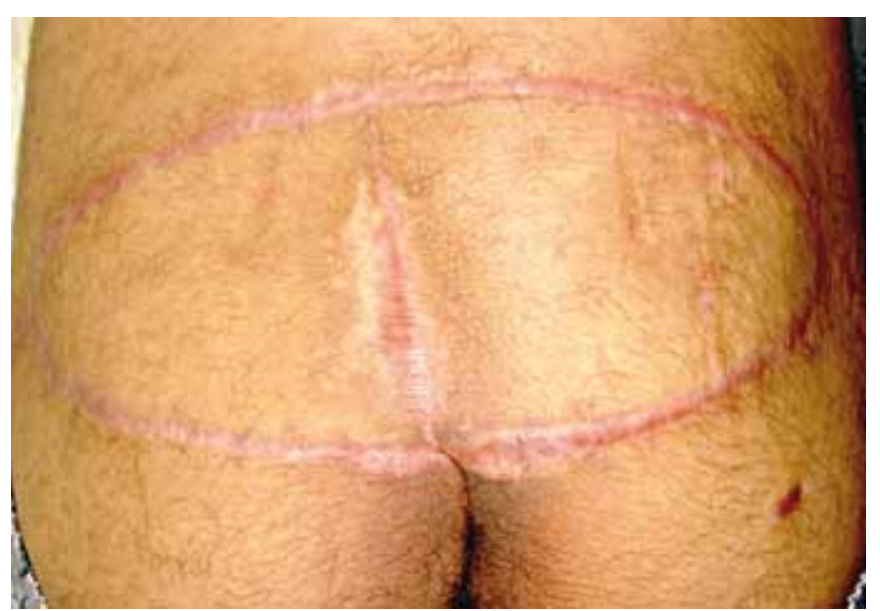

Figure 8 - The fourth month of the postoperative period. Flap of gluteus maximus in $V-Y$, bilateral. 


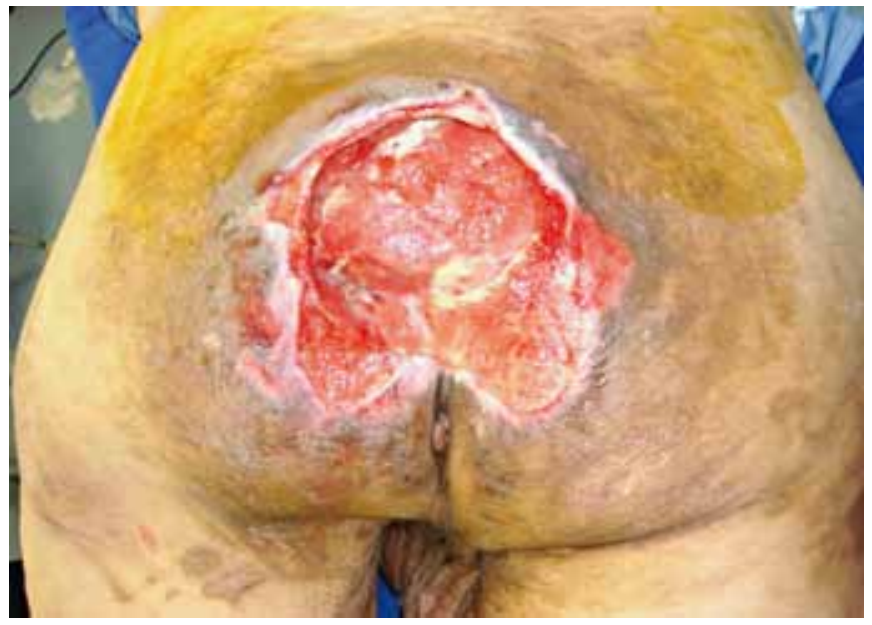

Figure 9 -Sacral ulcer in a 68-year-old stroke (CVA) patient.

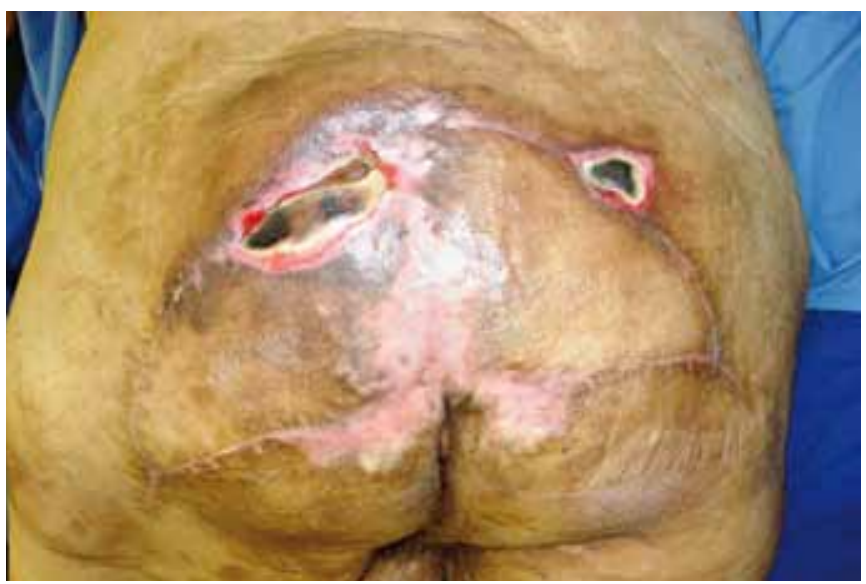

Figure 10 - Recurrence in the eighth month of the postoperative period.

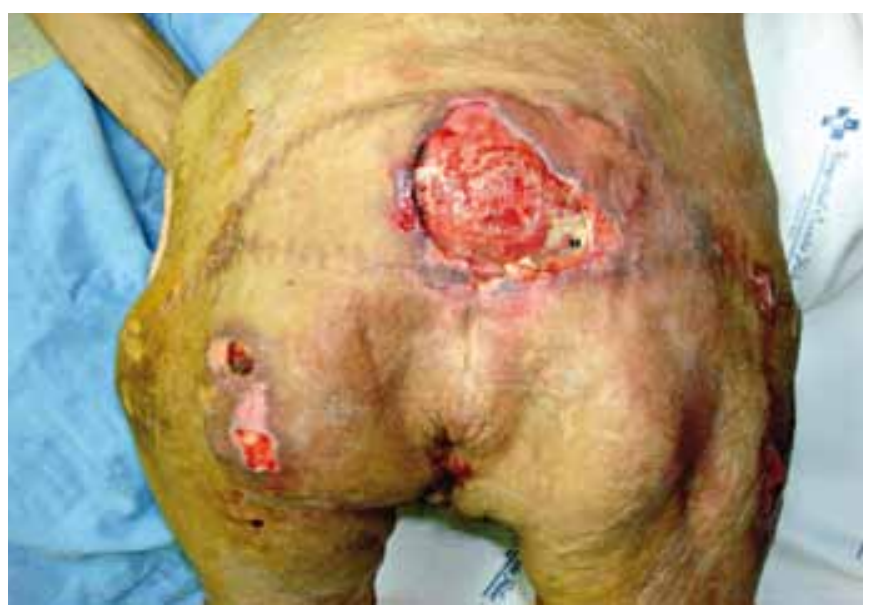

Figure 11 - Multiple recurrences in a 43-year-old stroke patient. Several areas with surgical scars are shown.

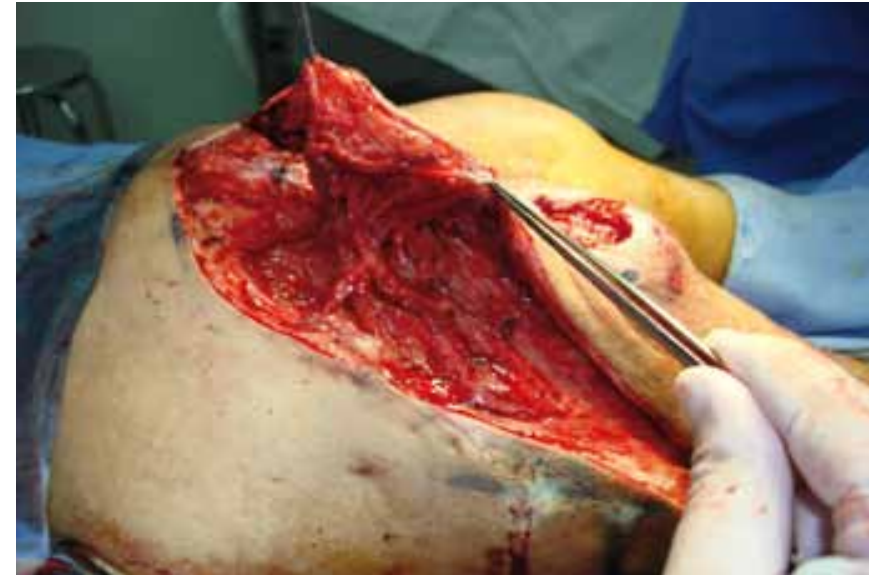

Figure 12 - Posterior flap of the thigh with gluteal extension. Note the maintenance of irrigation in the area of previous mobilization of the gluteus maximus flap in $V-Y$.

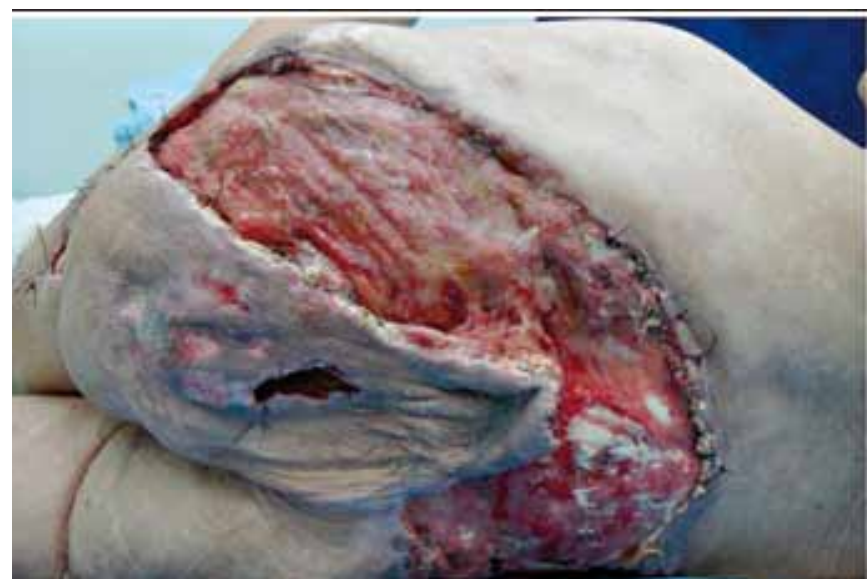

Figure 13 - Dehiscence of the posterior flap of the thigh in $V-Y$ with gluteal extension. The flap's viability can be observed.

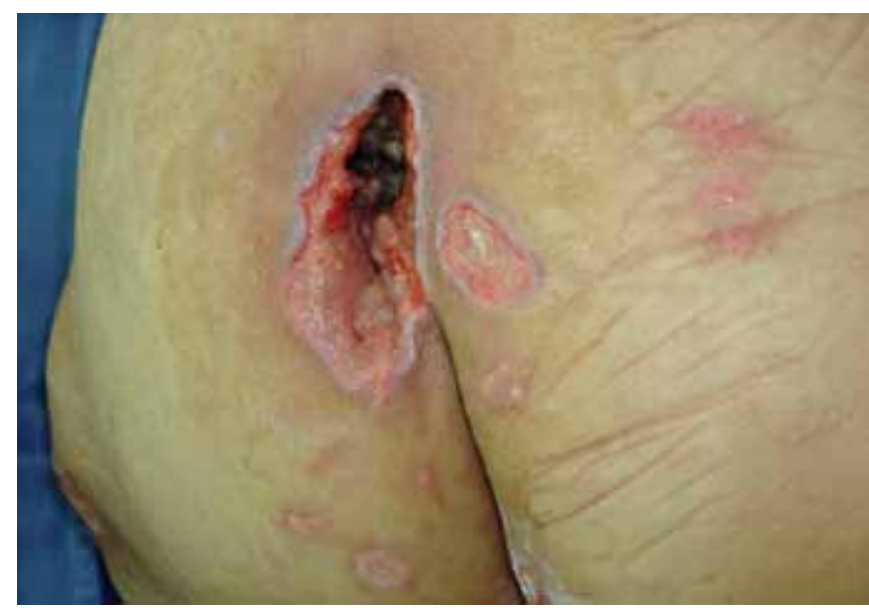

Figure 14 - A small

sacral ulcer. 


\section{DISCUSSION}

The case selection mostly included chronically ill and elderly patients, with an average age of 64 years, which is consistent with the type of populations in other studies ${ }^{5}$.

Plastic surgeon assessment was only requested when there was a total loss of skin, which explains the lack of grade I PU reports in this study.

Isolated debridement without flap preparation for coverage was carried out for the patient with grade II PU because of the clinical severity and for lesions located in areas of good prognosis for healing, such as the calcaneal region. The grade II calcaneal PU that underwent debridement healed approximately in 3 weeks.

According to a study conducted for clinical and epidemiological assessment of PU in patients admitted to Hospital São Paulo (São Paulo, SP), 68\% of PU cases developed in hospitals and $32 \%$ developed at home, in nursing homes, and in other clinics 5 . In this study, $82 \%$ of PU cases developed in the hospital and $18 \%$ developed at home. These findings, which suggest that these patients receive better treatment at home and in nursing homes than in the

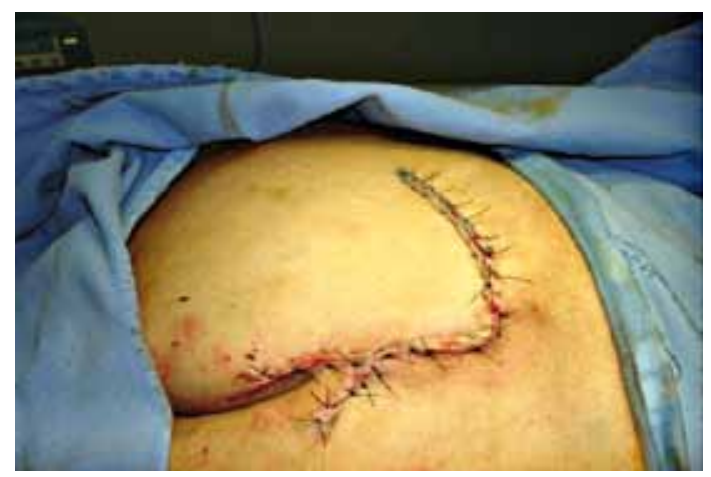

Figure 15 - Random flap of rotation.

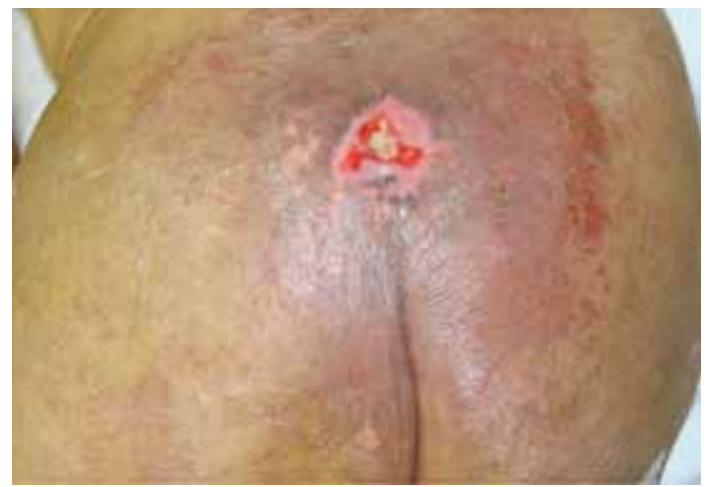

Figure 16-A small sacral ulcer. hospital, are of great importance because they indicate the need for guidance and hospital treatment systematization for patients with PU risk factors. The lower incidence of PU from the household in the results herein may be related to differences between the populations studied in this research and in the aforementioned study. In this study, the population was from private hospitals with better resources for home care. The high incidence of PU in the hospital is due to lack of knowledge about PU prevention in nursing and medical teams, as non-surgeons did not recommend changes in position in any case.

An important factor in PU genesis is excessive moisture, mostly resulting from fecal and urinary incontinence ${ }^{6}$. Only one patient was not incontinent in this study. Moisture macerates the skin, especially when under friction, leading to superficial lesions that are susceptible to infection.

The highest incidence of PU was in the sacral region, resulting from the greater frequency of the supine position in a population of patients with chronic diseases and the elderly. The flap of the gluteus maximus in V-Y was the most

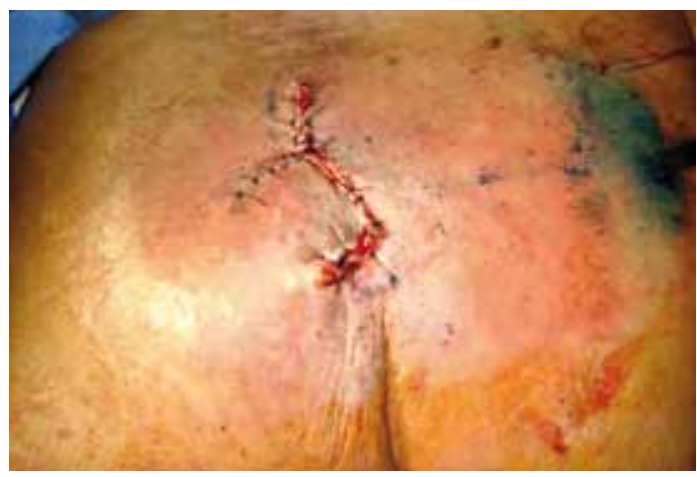

Figure 17-Rhomboid flap.

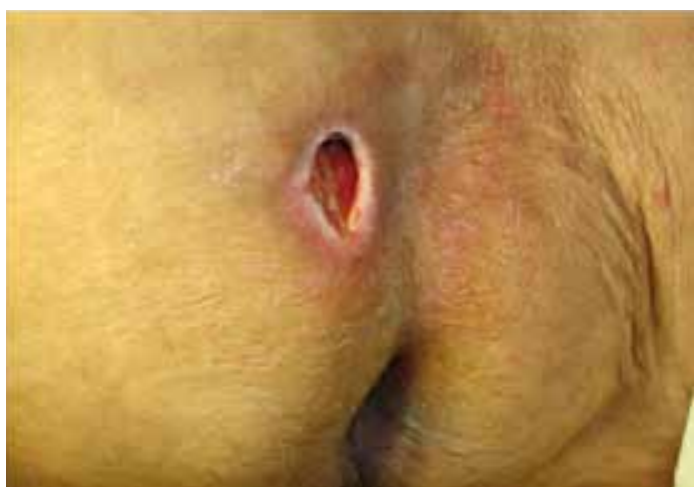

Figure 18 - Sacral ulcer with sagging skin and local tissue availability. 
frequently used, accounting for $21 \%$ of cases. This flap is easy to mobilize when unilaterally used, making it possible to reach the contralateral side and enabling the suture line to be isolated from the pressure zone ${ }^{20}$.

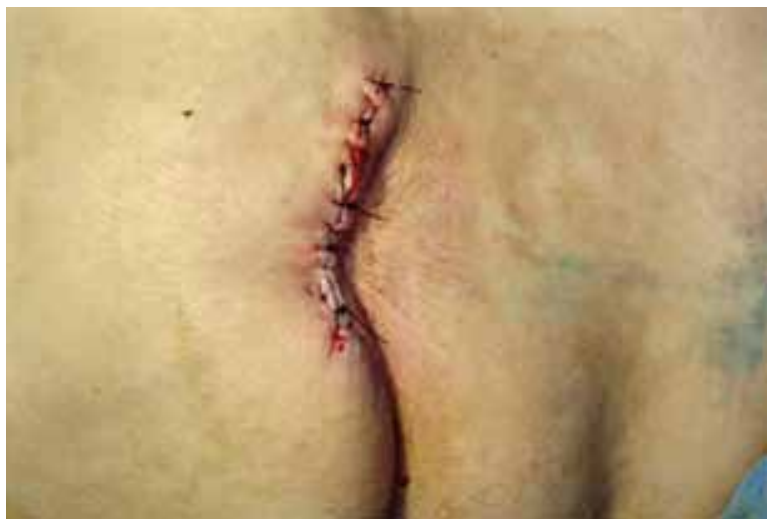

Figure 19 - Primary closure in sacral ulcer

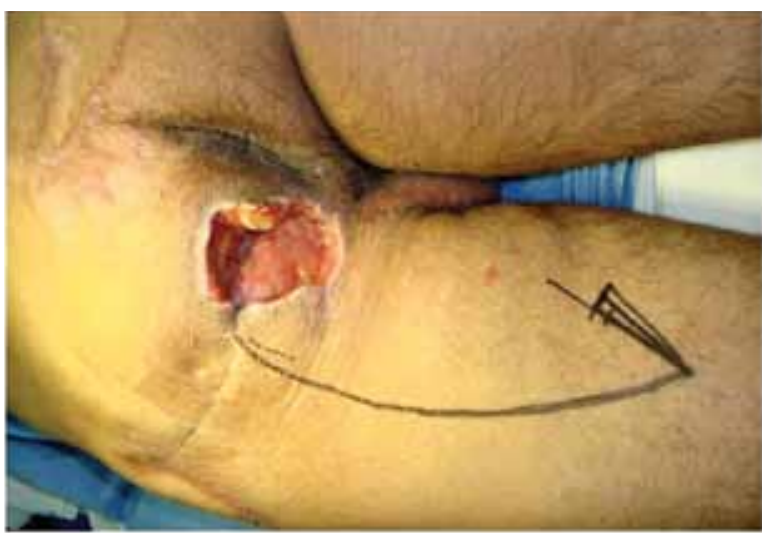

Figure 20-Ischial ulcer in a 50-year-old patient with spinal cord injury from a firearm bullet. Planning the posterior flap of the thigh in $V-Y$.

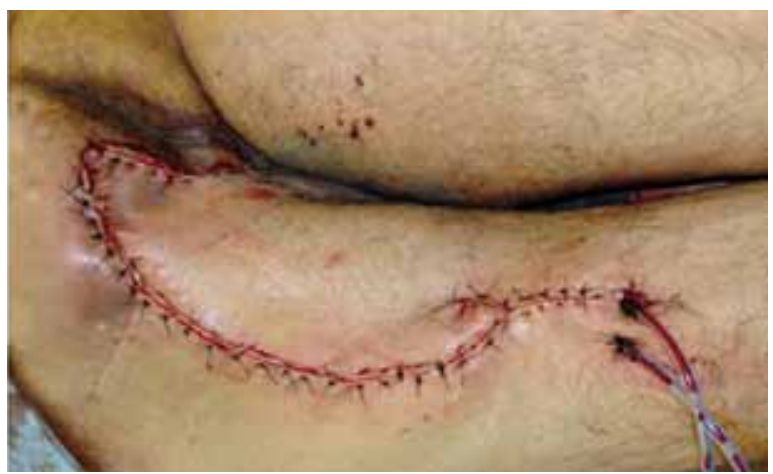

Figure 21 - Posterior flap of the thigh in $V-Y$.

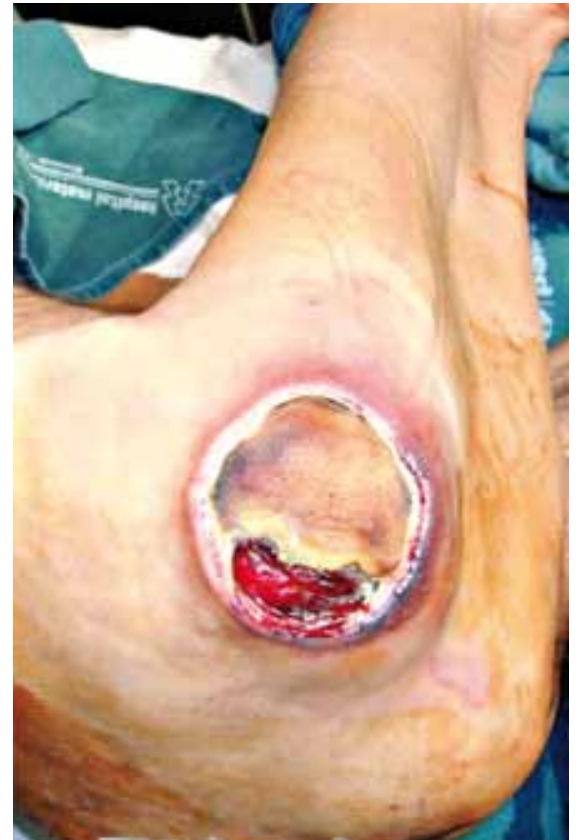

Figure 22 - Trochanteric ulcer in a 71-year-old patient.

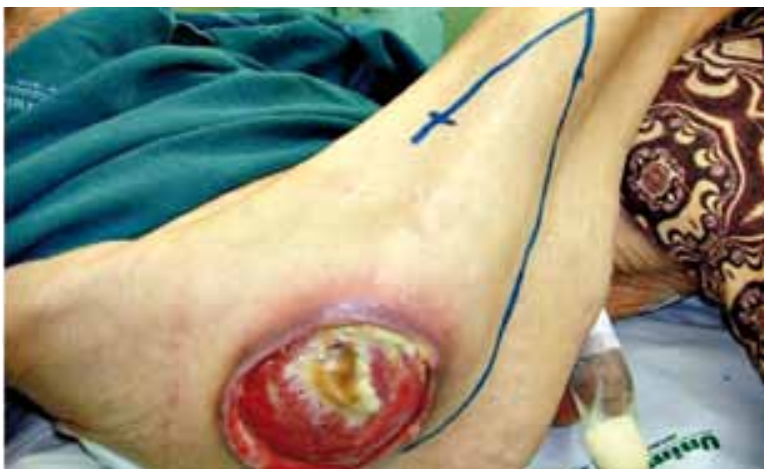

Figure 23 - Trochanteric ulcer in a 71-year-old patient. Planning a flap of fascia lata in $V-Y$.

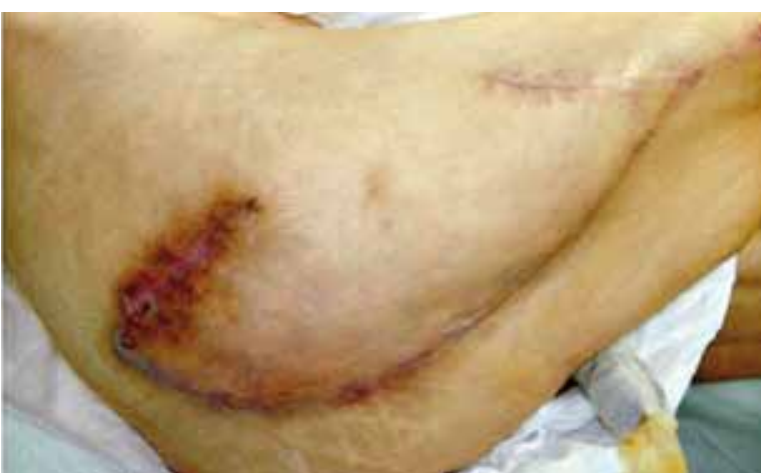

Figure 24 - Trochanteric ulcer in a 71-year-old patient. Planning a flap of fascia lata. 
Only two PU gluteus maximus musculocutaneous flaps in $\mathrm{V}-\mathrm{Y}$ were bilaterally prepared because of the large diameter of the affected area. In $71.5 \%$ of sacral ulcers, a unilateral gluteus maximus flap in $\mathrm{V}-\mathrm{Y}$ was performed in order to preserve the flap donor site in case of PU recurrence in the region.

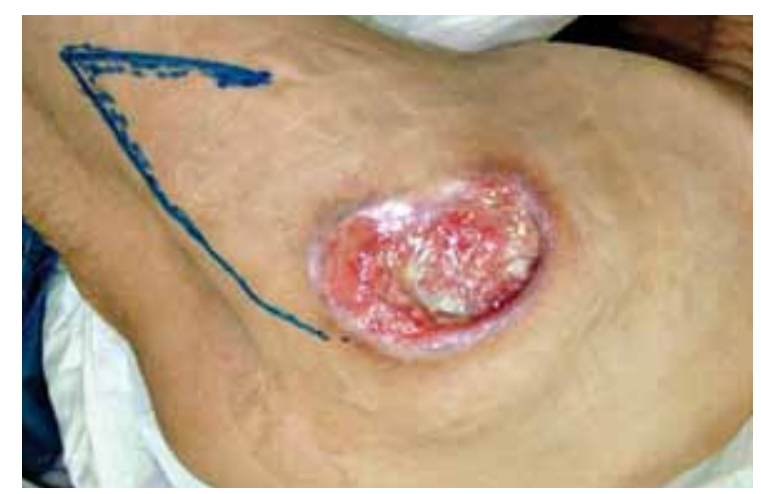

Figure 25 - The one-month postoperative period of the patient shown in Figures 22 to 24.

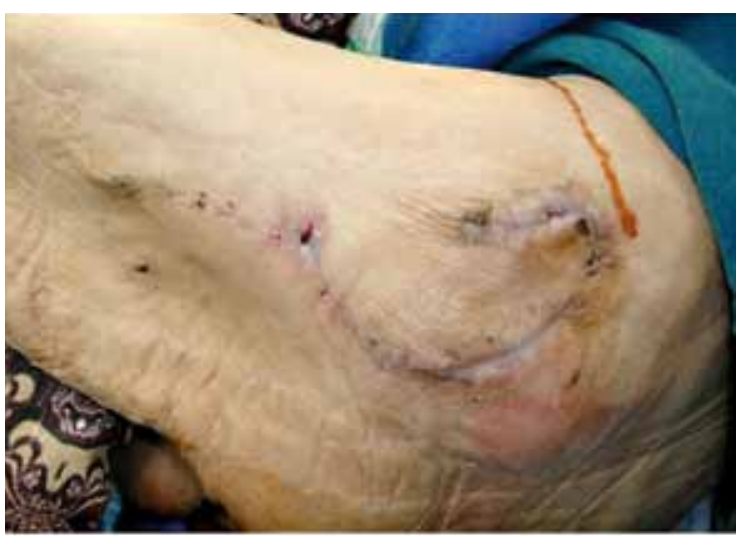

Figure 26 - The four-month postoperative period of the patient shown in Figures 22, 23, and 24.

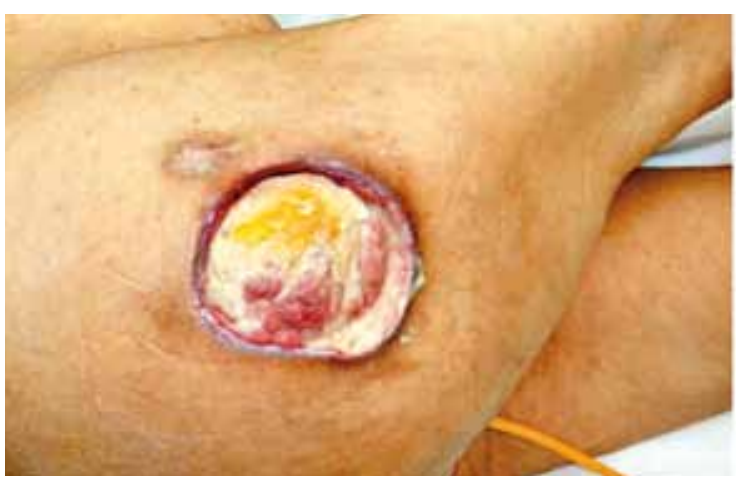

Figure 27 - Trochanteric ulcer.
Trochanteric ulcers often occur in patients in the lateral position. Reconstructions with classical fasciocutaneous flaps of fascia lata in V-Y were performed as well as debridement without flaps in patients with tissue necrosis that were clinically unstable.

PUs in the occipital and ear regions that corresponded to grade II ulcers and four grade III sacral ulcers underwent closure with primary synthesis. PUs that were not extensive and had available adjacent tissue were primarily closed to preserve the flap donor area in case of recurrence or new ulcer.

The posterior flap of the thigh in V-Y shows good vitality and can be performed with the medial or lateral base. It enables repair of isolated or multiple lesions in a single surgical procedure ${ }^{20}$. Two cases were performed with this flap: one involved repair of sacral and trochanteric ulcers in a single surgical procedure and the other was in the ischial region. This study included a single occurrence of ischial ulcers that developed with flap dehiscence $<3 \mathrm{~cm}$, which corresponded with a high complication rate in this region in other studies ${ }^{46,47}$.

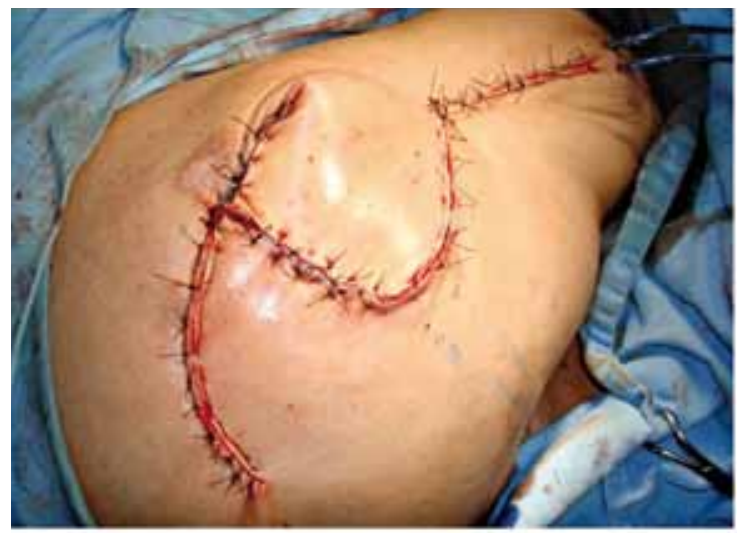

Figure 28 - Flap of fascia lata associated with random flap.

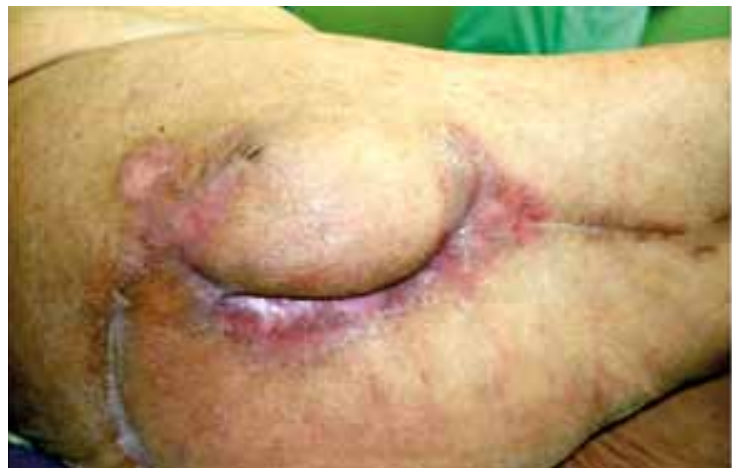

Figure 29 - The nine-month postoperative period of the patient shown in Figures 27 and 28. 
Random skin flaps were used preferentially in areas of ulcer recurrence with scars from previous reconstruction and in clinically unstable patients who required less surgical time.

After flap production, it is necessary to close the donor area without tension. The selection of the reconstructive procedure depends on several factors: level of spinal cord injury, ulcer area, history of prior ulcer and surgeries, prognosis, daily habits, nutritional status, and other associated medical problems.

Of the total cases with postoperative complications $(32 \%)$, half occurred in the sacral region. The high incidence in the region may have been related to contact with feces and urine near the surgical scar since all patients but one had urinary or fecal incontinence.

The attempt to correct albumin and hemoglobin to normal levels prior to surgery was not achieved in some patients because of chronic diseases. Albumin deficiency was not associated with postoperative complications but hemoglobin $<11 \mathrm{ng} / \mathrm{dl}$ (10.35 ng/dl on average) occurred predominantly with complications $(\mathrm{P}<0.05)$.

Although a patient with sacral PU had hemoglobin $<10$ $\mathrm{ng} / \mathrm{dl}$ without postoperative complications, anemia is usually associated with dehiscence and flap necrosis.

The low rate of ulcer recurrence ( $18 \%$ in six months) is probably related to the short follow-up time since other studies report rates above $26 \%{ }^{48}$. This fact may also be explained by the few reported cases of ischial ulcers because these have the greater recurrence rates ${ }^{46,47}$.

The success rate of $53 \%$ after one month of treatment, with complete closure of the ulcer and no recurrence, was observed for an average of six months, confirming the results of other studies ${ }^{43}$.

Routine assessment of impaired mobility in patients' skin may prevent PU formation since PU presents as either mild changes in skin color or no change in its initial phase. The difficulty in assessment is due to the failure of health professionals to differentiate between skin responses that are physiologically normal (reactive erythema) and pathological (non-reactive erythema), the latter of which will progress to later stages of PU if the causal stimulus is not eliminated.

The experience gained in this study contributed to a better surgical approach and non-surgical approach, the latter of which includes the participation of hospital staff, family members, and patients, in PU prevention.

\section{CONCLUSIONS}

PUs can be avoided in most cases given knowledge of their pathogenesis and proper management of patients at risk.

The involvement of patients, families, and/or professionals is essential for the successful treatment of patients with PU because complications and recurrences are common.
Risk factors for complications such as anemia shall be avoided for a better prognosis and proper closure of the PU.

\section{ACKNOWLEDGMENTS}

We thank Dr. Joel Veiga Filho, full member of the Brazilian Society of Plastic Surgery, for guidance during the development of this study.

\section{REFERENCES}

1. Santos LLR, Ferreira LM, Sabino Neto MS. Pressure ulcer. In: Ferreira LM, ed. Manual de cirurgia plástica. (Plastic surgery manual) São Paulo: Atheneu; 1995. p. 214-7.

2. Ferreira LM, Calil JA. Etiopatogenia e tratamento das úlceras por pressão. (Ethiopathogeny and pressure ulcers treatment) Diagn Tratamento. 2001;6:36-40.

3. Frisoli Jr A, Haddad A, Toniolo Neto J, Ferreira LM. Pressure ulcer. Gerontologia. (Gerontology) 1995;3:193-200.

4. Shea JD. Pressure sores: classification and management. Clin Orthop Relat Res. 1975;(112):89-100.

5. Blanes L, Duarte IS, Calil JA, Ferreira LM. Avaliação clínica e epidemiológica das úlceras por pressão em pacientes internados no Hospital São Paulo. (Clinical and epidemiological assessment of pressure ulcers in patients admitted at Hospital São Paulo) Rev Assoc Med Bras. 2004;50(2):182-7.

6. Bryant RA, Shannon ML, Pieper B, Braden BJ, Morris DJ. Pressure ulcers. In: Bryant RA, ed. Acute and chronic wounds: nursing management. St. Louis: Mosby; 1992. p. 105-63.

7. Lindan O, Greenway RM, Piazza JM. Pressure distribution on the surface of human body. I. Evaluation in lying and sitting positions using a "bed of springs and nails". Arch Phys Med Rehabil. $1965 ; 46: 378-85$

8. Dansereau JG, Conway H. Closure of decubiti in paraplegics. Report of 2000 cases. Plast Reconstr Surg. 1964;33:474-80.

9. Costa MP, Sturtz G, Costa FPP, Ferreira MC, Barros Filho TEP. Epidemiologia e tratamento das úlceras de pressão: experiência de 77 casos. (Epidemiology and treatment of pressure ulcers: experience of 77 cases) Acta Ortop Bras. 2005;13(3):124-33.

10. Bergstrom N, Braden B, Kemp M, Champagne M, Ruby E. Multi-site study of incidence of pressure ulcers and the relationship between risk level, demographic characteristics, diagnoses, and prescription of preventive interventions. J Am Geriatr Soc. 1996;44(1):22-30.

11. Dealey C. Cuidando de feridas: um guia para enfermeiras. (Wounds care: a guide for nurses) São Paulo: Atheneu; 1992. p. 83-126.

12. Allman RM. Pressure ulcers among the elderly. N Engl J Med. 1989;320(13):850-3.

13. Pinchcofsky-Devin GD, Kaminski MV Jr. Correlation of pressure sores and nutritional status. J Am Geriatr Soc. 1986;34(6):435-40.

14. Krasner D, Margolis DJ, Ordona RU, Rodeheaver GT. Prevention and management of pressure ulcers: treatment of chronic wounds. Number 6 in a Series.

15. Foster RD, Anthony JP, Mathes SJ, Hoffman WY, Young D, Eshima I. Flap selection as a determinant of success in pressure sore coverage. Arch Surg. 1997;132(8):866-73.

16. Powel PH. Pressure sore. In: Selected Readings in Plastic Surgery, 7(39):1-27.

17. Yarkony GM. Pressure ulcers: a review. Arch Phys Med Rehabil 1994;75(8):908-17.

18. National Pressure Ulcer Advisory Panel. Pressure ulcers: incidence, economics, risk assessment. Consensus Development Conference Statement. West Dundee: S-N Publications; 1989. 
19. Conway H, Griffith BH. Plastic surgery for closure of decubitus ulcers in patients with paraplegia: based on experience with 1,000 cases. Am J Surg. 1956;91(6):946-75.

20. Calil JA, Ferreira LM, Neto MS, Castilho HT, Garcia EB. Avaliação clínica do retalho fascio-cutâneo da região posterior da coxa em V-Y. (Clinical assessment of the fasciocutaneous flap from the posterior region of the thigh in V-Y) Rev Assoc Med Bras. 2001;47(4):311-9.

21. Conway H, Kraissl CJ, Clifford III RH. The plastic surgical closure of decubitus ulcers in patients with paraplegia. Surg Gynecol Obstet. 1947;85(3):321-32.

22. Wesser DR, Kahn S. The reversed dermis graft in the repairs of decubitus ulcers. Plast Reconstr Surg. 1967;40(3):252-4.

23. CampbellRM, Converse JM. The saddle-flap for surgical repair of ischial decubitus ulcers. Plast Reconstr Surg. 1954;14(6):442-3.

24. Luscher NJ, Kuhn W, Zäch GA. Rhomboid flaps in surgery for decubital ulcers: indications and results. Ann Plast Surg. 1986;16(5):415-21.

25. Rosen JM, Mo ST, Liu A. Experience with the island inferior gluteal thigh flap compared with other local flaps for the reconstruction of the pelvic area. Ann Plast Surg. 1990;24(6):498-509.

26. Hurwitz DJ, Swartz WM, Mathes SJ. The gluteal thigh flap: a reliable, sensate flap for the closure of buttocks and perineal wounds. Plast Reconstr Surg. 1981;68(4):521-32.

27. Rubin JA, Whetzel TP, Stevenson TR. The posterior thigh fasciocutaneous flap: vascular anatomy and clinical application. Plast Reconstr Surg. 1995;95(7):1228-39.

28. Maruyama Y, Ohnishi K, Takeuchi S. The lateral thigh fascio-cutaneous flap in the repair of ischial and trochanteric defects. Br J Plast Surg. 1984;37(1):103-7.

29. Paletta C, Bartell T, Shehadi S. Applications of the posterior thigh flap. Ann Plast Surg. 1993;30(1):41-7.

30. Yamamoto Y, Ohura T, Shintomi Y, Sugihara T, Nohira K, Igawa H. Superiority of the fasciocutaneous flap in reconstruction of sacral pressure sores. Ann Plast Surg. 1993;30(2):116-21.

31. Scheflan M, Nahai F, Bostwick J 3rd. Gluteus maximus island musculocutaneous flap for closure of sacral and ischial ulcers. Plast Reconstr Surg. 1981;68(4):533-8.

32. Ramirez OM. The sliding plication gluteus maximus musculocutaneous flap for reconstruction of sacrococcygeal wounds. Ann Plast Surg. 1990;24(3):223-30.

33. Ger R. The surgical management of decubitus ulcers by muscle transposition. Surgery. 1971;69(1):106-10.

34. Klein NE, Luster S, Green S, Moore T, Capen D. Closure of defects from pressure sores requiring proximal femoral resection. Ann Plast Surg. 1988;21(3):246-50.
35. Arregui J, Cannon B, Murray JE, O’Leary JJ Jr. Long-term evaluation of ischiectomy in the treatment of pressure ulcers. Plast Reconstr Surg. 1965;36(6):583-90.

36. Pers M, Snorrason K, Nielsen IM. Primary results following surgical treatment of pressure sores. Scand J Plast Surg. 1986;20(1):123-4.

37. Keys KA, Daniali LN, Warner KJ, Mathes DW. Multivariate predictors of failure after flap coverage of pressure ulcers. Plast Reconstr Surg. 2010;125(6):1725-34.

38. Disa JJ, Carlton JM, Goldberg NH. Efficacy of operative cure in pressure sore patients. Plast Reconstr Surg. 1992;89(2):272-8.

39. Estrella EP, Lee EY. A retrospective, descriptive study of sacral ulcer flap coverage in nonambulatory patients with hypoalbuminemia. Ostomy Wound Manage. 2010;56(3):52-9.

40. Ichioka S, Okabe K, Tsuji S, Ohura N, Nakatsuka T. Distal perforatorbased fasciocutaneous V-Y flap for treatment of sacral pressure ulcers. Plast Reconstr Surg. 2004;114(4):906-9

41. Lee HB, Kim SW, Lew DH, Shin KS. Unilateral multilayered musculocutaneous V-Y advancement flap for treatment of pressure sore. Plast Reconstr Surg. 1997;100(2):340-5.

42. Jósvay J, Sashegyi M, Kelemen P, Donáth A. Modified tensor fascia lata musculofasciocutaneous flap for the coverage of trochanteric pressure sores. J Plast Reconstr Aesthet Surg. 2006;59(2):137-41.

43. Maciel SC, Tavares Filho JM, Belerique M. Retalhos glúteos em V-Y para reparação de úlceras sacras, isquiáticas e trocantéricas, sem secção ou sacrifício do músculo glúteo máximo. (Gluteal flaps in V-Y for repair of sacral, ischiatic and throcanteric ulcers without section or sacrifice of the gluteus maximum muscle) Rev Soc Bras Cir Plast. 1999;14(2):55-64.

44. Calil JA. Aplicação clínica do retalho fáscio-cutâneo em V-Y da região posterior da coxa [tese de doutorado]. (Clinical application of the fasciocutaneous flap in $\mathrm{V}-\mathrm{Y}$ from the posterior region of the thigh $[\mathrm{PhD}$ thesis] São Paulo: Universidade Federal de São Paulo; 1999.

45. Jones NF, Wexler MR. Delineation of the pressure sore bursa using methylene blue and hydrogen peroxide. Plast Reconstr Surg. 1981;68(5):798-9.

46. Relander M, Palmer B. Recurrence of surgically treated pressure sores. Scand J Plast Reconstr Surg Hand Surg. 1988;22(1):89-92.

47. Kierney PC, Engrav LH, Isik FF, Esselman PC, Cardenas DD, Rand RP. Results of 268 pressure sores in 158 patients managed jointly by plastic surgery and rehabilitation medicine. Plast Reconstr Surg. 1998;102(3):765-72.

48. Souza Filho MVP, Cardoso DP, Girão RA. Tratamento cirúrgico das úlceras de pressão com retalhos cutâneos e musculocutâneos. (Surgical treatment of pressure ulcers with skin and musclecutaneous flaps) Experiência de três anos no Hospital Geral Dr. Waldemar de Alcântara. Rev Bras Cir Plast. 2009;24(3):274-80.

\section{Correspondence to:}

Ricardo Goes Figueiras

Rua Rio Madeira, 6 - Quadra 37 - Vieiralves - Manaus, AM, Brazil - CEP 69053-030

E-mail: rgoes@vivax.com.br 